\begin{tabular}{|c|c|c|c|c|c|c|}
\hline \multirow{2}{*}{$\begin{array}{c}\text { Массовая доля } \\
\text { общего сахара, \% }\end{array}$} & \multirow{2}{*}{\multicolumn{2}{|c|}{$\begin{array}{c}\text { Йодометричес } \\
\text { кий метод [4] } \\
\text { Феррицианид } \\
\text { ныйметод [4] }\end{array}$}} & $23,24 \pm 0,71$ & $16,12 \pm 0,93$ & $25,67 \pm 0,51$ & \multirow{2}{*}{$>35,0$} \\
\hline & & & $19,52 \pm 0,80$ & $15,63 \pm 0,69$ & $23,58 \pm 0,97$ & \\
\hline \multirow{3}{*}{$\begin{array}{c}\text { Тяжелые } \\
\text { металлы, мг/кг }\end{array}$} & \multirow{3}{*}{$\begin{array}{c}\text { ИВА } \\
\text { [6] }\end{array}$} & $\mathrm{Zn}$ & \multicolumn{3}{|c|}{$<0,010$} & 30,0 \\
\hline & & $\mathrm{Cd}$ & \multicolumn{3}{|c|}{$<0,005$} & 0,1 \\
\hline & & $\mathrm{Pb}$ & \multicolumn{3}{|c|}{$<0,002$} & 0,5 \\
\hline
\end{tabular}

Таким образом, по исследованным показателям образцы соответствуют значениям нормативной документации $[1,8]$.

$$
* * *
$$

1. ГОСТ 24901-2014. Печенье. Общие технические условия.

2. ГОСТ 5898. Изделия кондитерские. Методы определения кислотности и щелочности.

3. ГОСТ 5900-2014. Изделия кондитерские. Методы определения влаги и сухих веществ.

4. ГОСТ 5903-89. Изделия кондитерские. Методы определения сахара.

5. ГОСТ 5901-2014. Изделия кондитерские. Методы определения массовой доли золы и металломагнитной примеси.

6. ГОСТ 30178-96. Сырьё и продукты пищевые. Атомно-абсорбционный метод определения токсичных элементов.

7. Коренман Я.И., Лисицкая Р.П. Практикум по аналитической химии. Анализ пищевых продуктов. Воронеж. 2002. - 408 c.

8. Скурихин И.М., Нечаев А.П. Все о пище с точки зрения химика. - М.: ВШ, 1991. - 288 с.

\title{
Mahnur Jafarli \\ Equilibirium of ionite amberlite IRP-69, dowex MAC 3 - cd2+, pb2+ metal ion system
}

Institute of Natural Resourses, Nakhchivan branch (Azerbaijan)

doi: $10.18411 / \mathrm{j}-28-02-2018-49$

idsp: 000001:lj-28-02-2018-49

The aticle presents the results of the kinetics of the equilibrium condition of interaction of $\mathrm{Pb} 2+$ and $\mathrm{Cd} 2+$ ions with strong and weakly acid properties of Amberlite IRP-69 (sulphogroup) and Dowex MAC 3 (carboxyl functional group) cationites and the values of thermodynamic quantities calculated on the basis of these. Equilibrium condition of the processes has been evaluated according to sorption isotherms and values of change constant. The starting parts of isotherms, formed by variable concentrations method, are linear with the convex curves. Since the sorption processes are accompanied by the $\mathrm{H}+-\mathrm{Me} 2+$ change, the value of the change constant is assumed as the changing of a monovalent ion to the bivalent ion.

The change of parameters, such as energy and entropy of activation, free energy of sorption and diffusion coefficients change on various factors. Thermodynamic description of exchange of studied ions by exchangers was conducted on the assumption of ideality of the solid phase, i.e, without taking into account the activity coefficients of ions in the absorbed state. The value of the entropy of activation was calculated from the equation proposed by R.M.Barrer and his collaborators: $\mathrm{D} 0=\mathrm{d} 2(\mathrm{ekT} / \mathrm{h}) \exp (\Delta \mathrm{S} * / \mathrm{R})$.

In the results of the calculations from low concentrated solutions $\mathrm{K}$ is characterized by small value but higher value from higher concentrated solutions. The kinetics of the processes are studied from $\mathrm{C} 0=1.00 \mathrm{~g} \mathrm{Me} 2+\mathrm{L}-1$ concentrated solutions, the amount of metal ions that passes to the sorbent phase has been higher than $\mathrm{K}>1$. $\mathrm{K}=1.30$ for lead ion, $\mathrm{K}=1.28$ for cadmium ion with Dowex MAC 3 ionite, $K=5.75$ for lead ionite and $K=3.94$ for cadmium ionite with Amberlite IRP 69 are characterized by values. In experiments with relatively high concentrations $(>2.00 \mathrm{~g} \mathrm{Me} 2+\cdot \mathrm{L}-1)$, high values of $\mathrm{K}$ are obtained from the calculations. Such changes of the values of $\mathrm{K}$ have an impact on the values of genuine energy and enthalpy. 
In addition to ion exchange, the coordination relation with the free electron pairs of oxygen and nitrogen atoms in the ionites has also been approved during the interaction of ionitemetal ion with the method of IQS. IR spectra were drawn on the Nicolet iS10 FT-IR Spectrometery with the preparation of $\mathrm{KBr}$ pills. Thus, the displacement of the intensities of the absorbing zones belonging to the hydroxyl groups with their significant reduction, the participation of free oxygen atoms in complex forming. The same idea is also characteristic for $-\mathrm{N}=\mathrm{N}-$ diazo bridge in the functional group of Amberlite IRP-69. Significant decrease of the intensity of the frequency belongs to sorption zone of this group approves its participation in the formation of coordination communication. Kinetic and thermodynamic parameters of the studied processes have been calculated.

Kinetic and thermodynamic parameters that characterize of sorption of $\mathrm{Cd} 2+$ and $\mathrm{Pb} 2+-$ ions by cationite $(r 0=0.0315 \mathrm{sm} ; r 0=0.0275 \mathrm{sm})$.

\begin{tabular}{|c|c|c|c|c|c|c|c|}
\hline $\begin{array}{r}\mathrm{Di} \cdot 10^{-8} \\
\mathrm{sm}^{2} / \mathrm{sec} \\
\end{array}$ & $\begin{array}{l}\mathrm{D}_{0} \cdot 10^{-4} \\
\mathrm{sm}^{2} / \mathrm{sec} \\
\end{array}$ & $\begin{array}{c}\begin{array}{c}\mathrm{E}_{\text {akt }} \\
\mathrm{kJ} / \mathrm{mol}\end{array} \\
\end{array}$ & $\begin{array}{c}-\Delta \mathrm{S}^{*} \\
\mathrm{~J} / \mathrm{mol} \cdot \mathrm{K} \\
\end{array}$ & $\begin{array}{c}-\Delta \mathrm{H}^{0} \\
\mathrm{~kJ} / \mathrm{mol}\end{array}$ & $\begin{array}{c}-\Delta \mathrm{G} \\
\mathrm{kJ} / \mathrm{mol}\end{array}$ & $\mathrm{K}$ & $\begin{array}{c}\lambda^{2} \mathrm{e}^{\Delta S / R} \cdot 10 \\
{ }^{18,} \mathrm{sm}^{2}\end{array}$ \\
\hline \multicolumn{8}{|c|}{$\mathrm{Cd}^{2+}-$ Dowex MAC 3} \\
\hline 7.15 & 0.77 & 17.30 & 52.44 & 16.24 & 0.61 & 1.28 & 0.456 \\
\hline \multicolumn{8}{|c|}{$\mathrm{Pb}^{2+}-$ Dowex MAC 3} \\
\hline 6.90 & 0.836 & 17.60 & 51.76 & 16.07 & 0.65 & 1.30 & 0.495 \\
\hline \multicolumn{8}{|c|}{$\mathrm{Cd}^{2+}$ - Amberlite IRP 69} \\
\hline 3.5 & 6.90 & 24.5 & 34.2 & 40.8 & 14.13 & 3.94 & 4.9 \\
\hline \multicolumn{8}{|c|}{$\mathrm{Pb}^{2+}$ - Amberlite IRP 69} \\
\hline 3.2 & 17.3 & 27 & 26.73 & 12.3 & 4.33 & 5.75 & 10.3 \\
\hline
\end{tabular}

